\title{
Frameshift Mutations of Human Gastrin Receptor Gene (hGARE) in Gastrointestinal Cancers with Microsatellite Instability
}

\author{
Luigi Laghi, Guglielmina Nadia Ranzani, Paolo Bianchi, Antonio Mori, \\ Karl Heinimann, Ombretta Orbetegli, Marco Rondo Spaudo, Ombretta Luinetti, \\ Simona Francisconi, Massimo Roncalli, Enrico Solcia, and Alberto Malesci
}

\begin{abstract}
Division of Gastroenterology (LL, OO, SF, A. Malesci) and Department of Pathology (PB, MR), Istituto Clinico Humanitas, Rozzano-Milan, Departments of Genetics and Microbiology (GNR, A. Mori, MRS) and Human Pathology (OL, ES), University of Pavia, and IRCCS Policlinico S. Matteo, Pavia, and Departments of Pathology (MR) and Internal Medicine (A. Malesci), University of Milan, Milan, Italy; Research Group in Human Genetics (KH), University Hospital, Basel, Switzerland
\end{abstract}

\begin{abstract}
SUMMARY: Gastrointestinal tumors with DNA mismatch repair (MMR) defects show microsatellite instability (MSI) and harbor frameshift mutations in coding mononucleotide repeats of cancer-related genes (targets). We assessed MSI status in 233 sporadic gastrointestinal tumors. We classified as MSI-H (high-frequency microsatellite instability) 15 (10\%) of 150 colorectal cancers and $13(16 \%)$ of 83 gastric cancers. We searched for frameshift mutations in a coding poly $(T)_{8}$ tract within the gastrin receptor gene ( $h G A R E$ ), which has a potential role in gastrointestinal carcinogenesis. To this purpose, we screened 43 unstable tumors (including 15 hereditary nonpolyposis colorectal cancer cases previously classified as MSI-H), 98 stable tumors, as well as 3 MMR-deficient and 4 MMR-proficient gastrointestinal cancer cell lines. We found mutations in 8 (19\%) of the $43 \mathrm{MSI}-\mathrm{H}$ tumors but in none of the 98 stable cancers. hGARE mutation frequency was similar in gastric (23\%) and colorectal cancers, including sporadic $(13 \%)$ and hereditary $(20 \%)$ cases. All mutated tumors proved to harbor frameshift mutations in other cancer-related genes that are considered as targets in MSI tumorigenesis. The MMR-deficient and gastrin-sensitive LoVo colorectal cancer cells also showed a hGARE heterozygous frameshift mutation, but expressed only the mutated allele. All detected mutations can be predicted to generate a truncated protein carrying amino acid changes. On the basis of genetic findings, we propose $h G A R E$ as a new candidate target gene in MSI tumorigenesis. Functional studies are warranted to elucidate the mechanism by which the hGARE mutation might contribute to gastrointestinal carcinogenesis. (Lab Invest 2002, 82:265-271).
\end{abstract}

$T$ he cancers arising in most patients with hereditary nonpolyposis colorectal cancer (HNPCC) and a subset (10-20\%) of sporadic gastrointestinal tumors exhibit widespread genome instability that is manifested by increases in mutation rates and by alterations in the size of simple repeated sequences (Aaltonen et al, 1993; Ionov et al, 1993; Thibodeau et al, 1993). This tumor phenotype, called MSI (from microsatellite instability), is the result of alterations in DNA mismatch repair (MMR) genes, which play a crucial role in the maintenance of DNA-replication fidelity (reviewed by Peltomaki, 2001). Different molecular mechanisms have been found to inactivate MMR genes: germ line mutations, genomic rearrangements,

Received September 7, 2001.

The first two authors contributed equally to this paper.

This work was supported by Consiglio Nazionale delle Ricerche (grants to Alberto Malesci and ES), by Ministero Università e Ricerca (grant to GNR), and by Ministero Sanità (grant to IRCCS Policlinico S. Matteo, Pavia). MRS is a fellow of the Associazione Italiana Ricerca sul Cancro. Address reprint requests to: Dr. Alberto Malesci, Division of Gastroenterology, Istituto Clinico Humanitas, Via Manzoni, 56 - 20089 Rozzano (Milano), Italy.E-mail: alberto.malesci@humanitas.it and unbalanced allelic expression are involved in hereditary tumors (Charbonnier et al 2000; Curia et al, 1999; Peltomaki and Vasen, 1997), whereas somatic mutations and promoter hypermethylation play a major role in sporadic tumors (Herman et al, 1998; Kane et al, 1997; Liu et al, 1995).

MMR-deficient tumors frequently harbor insertions/ deletions in mononucleotide tracts within coding regions of genes involved in the control of cell proliferation and survival. Frameshift mutations of cancerrelated genes (targets) have been proposed to be under positive selective pressure during the evolution of unstable tumors (Yamamoto et al, 1997). A number of target genes have been implicated in the pathogenesis of MMR-deficient gastrointestinal cancers (Duval et al, 2001) and some of these genes have been found to be frequently mutated in these tumors. These include the growth factor receptor genes TGF $\beta R I I$ (Markowitz et al, 1995) and IGFIIR (Souza et al, 1996), the proapoptotic gene BAX (Rampino et al, 1997), the DNA-MMR genes $h M S H 3, h M S H 6$ (Malkhosyan et al, 1996), and MED1 (Bader et al, 1999; Riccio et al, 1999), the protease CASP-5 gene (Schwartz et al, 
1999), the transcription factor TCF-4 gene (Duval et al, 1999a), and the retinoblastoma protein interacting zinc finger RIZ gene (Piao et al, 2000). The identification of new targets might contribute to elucidating the progression pathway of MMR-deficient tumors and even provide clues for cancer treatment (Boland et al, 1998).

We used the GenBank database to search for mononucleotide repeats within the coding regions of growth factor and growth factor receptor genes possibly related to gastrointestinal tumorigenesis. We found a $(T)_{8}$ repeat in exon 5 of the human gastrin receptor gene ( $h G A R E$, or CCKBR). The peptide hormone gastrin represents a recognized growth factor for gastrointestinal tumor cells (lwase et al, 1997; Kusyk et al, 1986; Seva et al, 1994; Singh et al, 1994; Stepan et al, 1999). In addition, gastrin and CCK-B receptor, the expression of which is low or absent in normal colon (Monstein et al, 1996; Wank, 1998), have been proposed to be involved in maintaining autocrine/paracrine growth pathways in gastrointestinal cancer cells (McWilliams et al, 1998). To verify whether unstable tumors harbor $h G A R E$ frameshift mutations, we analyzed the $(T)_{8}$ repeat of exon 5 in a panel of both stable and unstable gastric and colorectal cancers, as well as in MMR-deficient/proficient cell lines derived from gastrointestinal tumors.

\section{Results}

We assessed MSI status in 233 sporadic gastrointestinal tumors. On the basis of recently established consensus criteria (Boland et al, 1998), we classified as MSI-H 15 (10\%) of 150 colorectal cancers and 13 $(16 \%)$ of 83 gastric cancers.

We analyzed $\mathrm{MSI}-\mathrm{H}$ tumors for insertions/deletions within coding repeats of TGF $\beta R I I, C A S P-5, B A X$, $h M S H 3, h M S H 6$, and IGFIIR target genes. As expected, somatic mutations proved to occur in all of these genes, although with different frequencies. The prevalence of gene mutations are reported in Table 1.

We searched for insertion/deletion mutations of hGARE gene in 43 unstable and 98 stable tumors, as well as in 3 MMR-deficient and 4 MMR-proficient cell lines derived from gastrointestinal tumors. Unstable tumors included 13 gastric and 15 sporadic colorectal cancers that we identified during this survey, as well as 15 HNPCC cases previously classified as MSI-H. Stable tumors included 28 colorectal and 70 gastric cancers. Genomic DNA were used to amplify the
hGARE exon-5 sequence encompassing the $(T)_{8}$ repeat. We analyzed polymerase chain reaction (PCR) products either by sequencing gel or by capillary electrophoresis. To avoid misclassifications, PCR products from each tumor and corresponding normal tissue were analyzed in parallel.

Among cancer cell lines, only MMR-deficient LoVo cells showed an $h G A R E$ heterozygous mutation due to a 1-bp deletion within the $(T)_{8}$ repeat. Seven 1-bp deletion and one 1-bp insertion mutations were found in $8(19 \%)$ of $43 \mathrm{MSI}-\mathrm{H}$ gastrointestinal tumors, but in none of the 98 stable cancers. The frequency of mutation was similar in gastric (3 of 13, 23\%) and colorectal cancers of both sporadic ( 2 of $15,13 \%)$ and hereditary (3 of $15,20 \%$ ) types. All tumors showing frameshift mutations also showed a wild type allele. This indicates that neoplastic cells were heterozygous for the observed mutations and/or that non-neoplastic cells contributing the normal allele were present in the tissue sections used for DNA extraction. Figure 1 shows 1-bp deletion mutations as detected by capillary (A) and gel electrophoresis (B).

DNA sequencing confirmed the deletion of $1 \mathrm{bp}$ within the $(T)_{8}$ repeat of $h G A R E$ exon 5 in the LoVo cells (Fig. 2) and in seven MSI-H tumors. This mutation, leading to a premature stop at codon 377 , is predicted to generate a truncated protein carrying amino acid changes. Sequencing also confirmed the insertion of $1 \mathrm{bp}$, causing a stop mutation at codon 350 , in one gastric cancer. In a gastric cancer harboring a $(T)_{7}$ repeat, DNA-sequencing revealed a missense mutation ( $\mathrm{G} \rightarrow \mathrm{A}$ transition; $\mathrm{Val} \rightarrow \mathrm{Ile}$ ) at codon 339. By cloning the PCR product from genomic DNA and by sequencing different clones, we assessed that frameshift and missense mutations were located on different alleles (Fig. 3). The functional significance, if any, of the missense mutation remains unclear. Among the eight $h G A R E$ mutated tumors, six also harbored a frameshift mutation of TGF $\beta R / l$ gene, four of $B A X$, three of $h M S H 3$, four of $h M S H 6$, and three of IGFIIR.

To evaluate $h G A R E$ expression, we performed RTPCR experiments on LoVo and HCT116 MMRdeficient colon cancer cell lines. By using 30 amplification cycles and specific primers encompassing hGARE exons 4 and 5, we could detect a single PCR product in LoVo but not in HCT116 cells (Fig. 4a); a PCR product was detectable in HCT116 cells only by reaching 50 amplification cycles. Direct sequencing of

Table 1. Frameshift Mutations at Coding Repeats of Target Genes in High-Frequency Microsatellite Instability Gastrointestinal Tumors

\begin{tabular}{|c|c|c|c|c|c|c|c|}
\hline & $n$ & $\begin{array}{c}\text { TGF } \beta R I I \\
n(\%)\end{array}$ & $\begin{array}{c}\text { CASP-5 } \\
n(\%)\end{array}$ & $\begin{array}{c}B A X \\
n(\%)\end{array}$ & $\begin{array}{c}\text { hMSH3 } \\
n(\%)\end{array}$ & $\begin{array}{c}\text { hMSH6 } \\
n(\%)\end{array}$ & $\begin{array}{c}\text { IGFRII } \\
n(\%)\end{array}$ \\
\hline Colorectal cancers & $30^{a}$ & $24(80)$ & $16(53)$ & $14(46)$ & $6(20)$ & $8(26)$ & $6(20)$ \\
\hline Gastric cancers & $12^{b}$ & $9(75)$ & nd & 2 (16) & $2(16)$ & $6(50)$ & $4(33)$ \\
\hline
\end{tabular}


cell lines $\quad$ CRC \# 136 HNPCC \# $10 \quad$ CRC \# 11

A

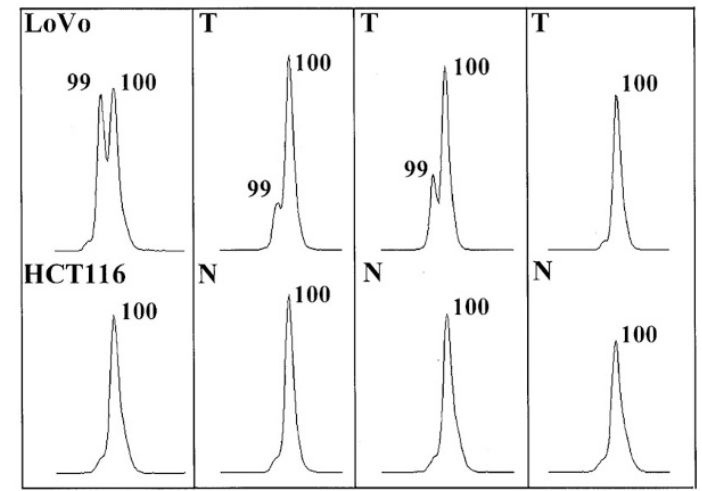

B

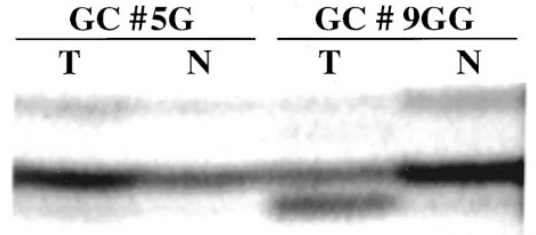

Figure 1.

hGARE frameshift mutations. T, tumor DNA; N, DNA from normal tissue. A, Electropherograms of fluoresceinated PCR-products from colon cancer cell lines (LoVo and HCT116) and from sporadic (CRC\#136 and CRC\#11) and hereditary (HNPCC\#10) colorectal cancers. Numbers indicate the length of the amplicons (in bp). Frameshift mutations are present in LoVo cells and in tumor DNA from samples CRC\#136 and HNPCC\#10. B, Gel electrophoresis of radiolabelled PCR-products from gastric cancers $(G C)$. A tumor sample $(G C \# 5 G)$ with a wild-type $(T)_{8}$ repeat, and a tumor sample (GC\#GGG) harboring a $\left(T_{7}\right.$ repeat are shown.

the product we obtained from LoVo cells demonstrated the presence of only one of the two isoforms that are known to be generated by exon 4 alternative splicing (Fig. 4c) (Song et al, 1993). Interestingly, this isoform corresponded with the hGARE frameshiftmutated allele and has been characterized by a $(T)_{7}$ repeat in exon 5 (Fig. 4b).

\section{Discussion}

We identified frameshift mutations within the $h G A R E$ exon 5 coding repeat in approximately $20 \%$ of the $\mathrm{MSI}-\mathrm{H}$ gastrointestinal tumors. This value is similar to values obtained for coding repeats of $h M S H 3$, hMSH6, and IGFIIR target genes in colorectal cancers, and for coding repeats of $h M S H 3, B A X$, and TCF-4 target genes in gastric cancers (see Table 1, and Duval et al, 1999b).

Mutation frequencies of coding repeats within genes that are potentially implicated in human carcinogenesis have recently been evaluated in a large series of MSI-H colorectal tumors. Using a statistical method, Duval et al (2001) separated genes into two groups, with a cut-off value for mutation frequency of about $12 \%$. Genes showing higher mutation frequencies have been proposed to represent valid "targets," the mutation of which is selected for and plays a role during tumorigenesis. Genes with lower mutation frequencies have been proposed to represent "bystanders," the mutation of which is probably due to the high background of instability present in MMR-deficient cells. In this respect, hGARE cancer-related gene is likely to represent a new target, the mutation of which may have functional significance.

On the other hand, the analysis of a number of noncoding (intronic) mononucleotide tracts has demonstrated that there is great variation in the prevalence of mutations among repeated sequences (Zhang et al, 2001). Some of the investigated tracts proved to be altered in less than $5 \%$ of the MMR-deficient tumors, whereas other tracts were altered in nearly $50 \%$ of the cases (Zhang et al, 2001). Very recently, it has been found that a large number of noncoding microsatellite mutations can accumulate in phenotypically normal MMR-deficient cells, even before the occurrence of a gatekeeper gene mutation, and in the absence of abnormal clonal expansion (Vilkki et al, 2001). Taken together these findings indicate that microsatellite instability in MSI-H tumors is a complex mechanism depending on different factors including size, nature, and localization of sequences, as well as functional significance. Therefore, the implication of a mutated gene as a target may present a difficulty in the absence of evidence that coding microsatellite mutations are functionally relevant in tumorigenesis (Boland et al, 1998; Zhang et al, 2001).

Frameshift mutations in the $h G A R E(T)_{8}$ repeat lead to major changes in the highly conserved structure of the CCKB receptor, a member of the superfamily of G-protein-coupled receptors possessing seven transmembrane domains (Wank, 1998). The VI transmembrane domain is modified in its amino acid sequence, whereas the VII domain and the intracellular $\mathrm{C}$-terminus are completely lost. It has been shown that the truncation of the carboxyl terminus of a G-proteincoupled receptor can result in constitutive activity (Matus-Leibovitch et al, 1995; Thomas et al, 1995). In particular, a rat CCKB receptor mutant, lacking the 44 carboxyl-terminal amino acids and closely resembling the putative receptor originating by $h G A R E$ frameshift mutations, has recently been shown to retain binding properties, G-protein coupling, and signal transduction activity (Pohl et al, 1997). Thus, the identified hGARE mutations might lead to a gain rather than a loss of the receptor function. Preliminary evidence in support of this concept derives from expression studies we performed on LoVo and HCT $116 \mathrm{MSI}-\mathrm{H}$ cancer cell lines. LoVo cells, which harbor an hGARE heterozygous mutation, are known to be responsive to the gastrin peptides growth stimulatory effect, whereas HCT 116 are nonresponsive (Stepan et al, 1999). We easily detected $h$ GARE mRNA in gastrinresponsive LoVo cells, but not in HCT 116 cells. In addition, LoVo cells proved to express only mRNA molecules corresponding to the frameshift mutated allele. Accordingly, LoVo have recently been shown to express at the cell surface only a gastrin receptor isoform of $40 \mathrm{kDa}$ (Watson et al, 1998), a molecular weight corresponding to that predicted for a truncated protein originating from the frameshift mutated hGARE gene. 

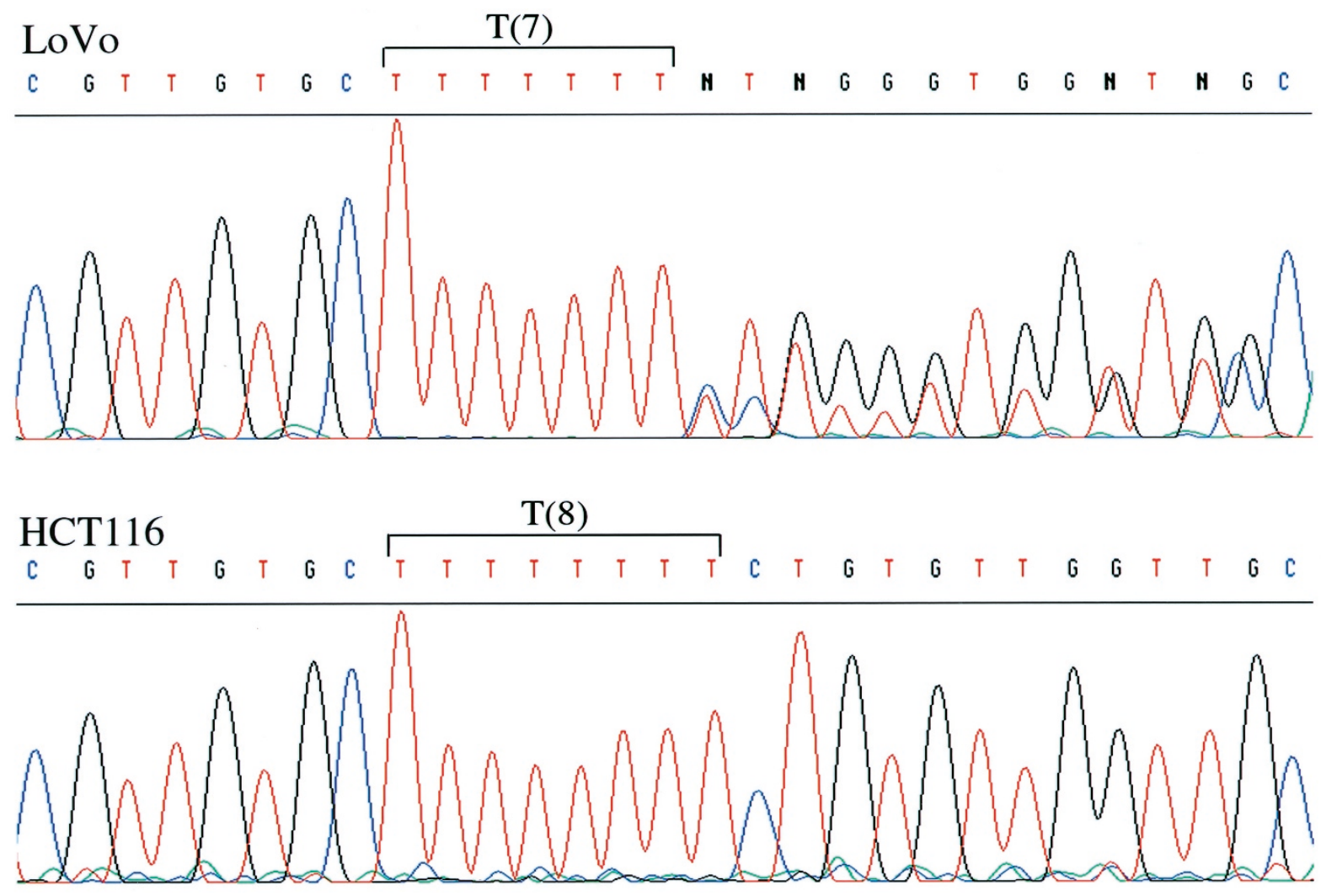

Figure 2.

DNA sequence of hGARE PCR products from LoVo and HCT116 cell lines. A frameshift mutation (1-bp deletion) within the $(\mathrm{T})_{8}$ repeat is detectable in LoVo cells, whereas a wild-type repetitive tract is present in HCT116 cells.

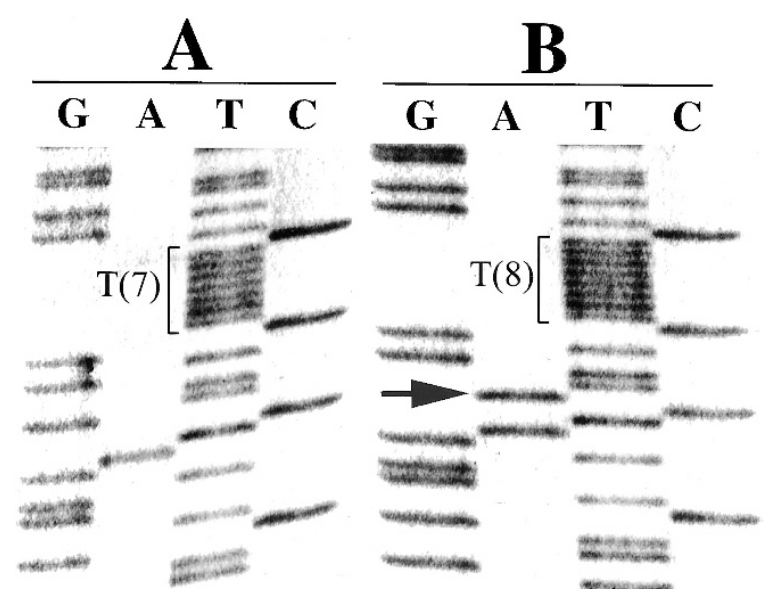

Figure 3.

DNA sequences of $h G A R E$ cloned PCR products from GC\#10G gastric cancer sample. $A(T)_{7}$ repeat is present in Clone $A ; a G \rightarrow A$ transition at codon 339 is present with a $(T)_{8}$ repeat in Clone $B$. The arrow indicates the $G \rightarrow A$ transition detected at codon 339 in Clone B.

Although a large body of data exists, further studies are needed on normal and tumor gastrointestinal tissues to definitely assess the role of gastrin and gastrin-receptors in both cell differentiation and proliferation. This makes it difficult to precisely evaluate the functional significance of the frameshift-mutated hGARE gene in unstable tumors. However, the presence of only mutated mRNA molecules in LoVo cells, which are known to grow in response to the gastrin, is consistent with a role of the putative truncated receptor in mediating a trophic effect. Taken together, our findings makes $h G A R E$ a new candidate target gene playing a role in the tumorigenesis of a fraction of unstable tumors.

\section{Materials and Methods \\ Cell Lines and Tumor Samples}

MMR-deficient cells from colon cancers (LoVo and HCT116) and from gastric cancers (SNU1), as well as MMR-proficient cells from colon cancers (HT29, FINCO1, FINCO2, and SW480), were kindly provided by Dr. G. Marra (Institute for Medical Radiobiology, Zurich, Switzerland) or purchased from the American Type Culture Collection (Manassas, Virginia).

The cancer panel included 150 consecutive colorectal cancers surgically resected at the Istituto Clinico Humanitas of Milan between 1997 and 1999 and 83 gastric cancers referred for histologic diagnosis to the Department of Pathology of the University of Pavia. Fifteen colorectal cancers from HNPCC patients, already classified as MSI-H, were obtained from the Department of Human Genetics of the University Hospital of Basel. 


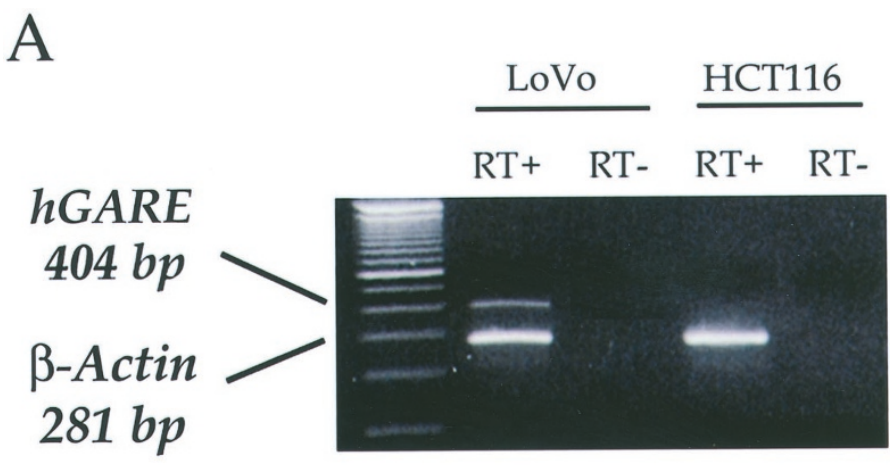

B

(T) 7
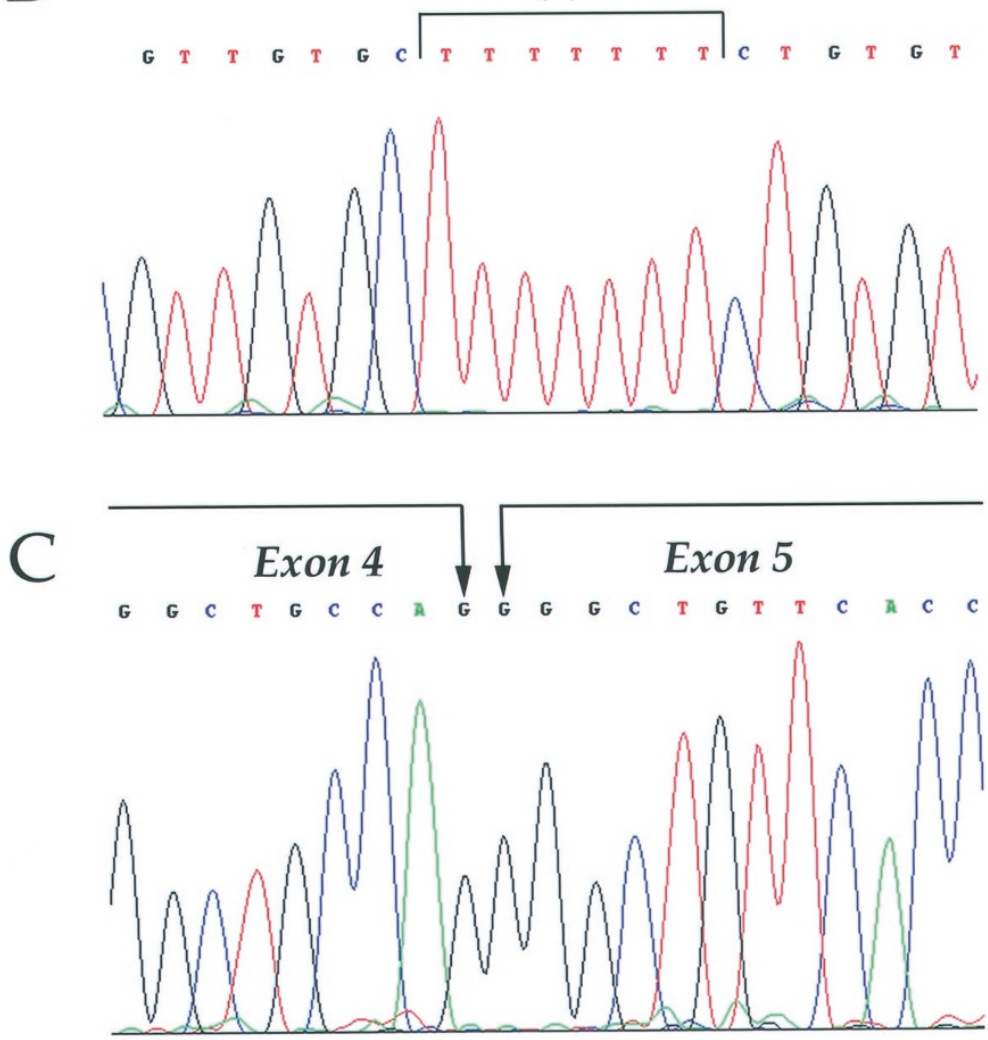

Figure 4.

hGARE mRNA expression in cancer cell-lines. A, A 404 bp hGARE RT-PCR product is detectable in LoVo, but not in HCT116 cells, whereas a 281 -bp $\beta$-actin RT-PCR product is present in both cell lines. RT+: , RT-: negative control. B and C, Direct sequencing of the LoVo hGARE RT-PCR product. As evident, only the exon 5 (T) 7 mutated allele is transcripted $(\mathrm{B})$, and only the short exon 4 splice variant isoform accounts for the hGARE expression (C).

\section{MSI-H Assessment and Target Gene Mutation Analysis}

DNA was purified by standard procedures from cancer cell lines and from paraffin sections of formalin-fixed specimens or from frozen tissue fragments of gastrointestinal tumors and matched normal mucosa. We searched for instability in tumor samples by screening a standard panel of microsatellite loci (Boland et al, 1998) according to the conditions reported by Dietmaier et al (1997). We amplified microsatellite sequences by using either radiolabeled or fluoresceinated specific primers. Accordingly, we analyzed PCR products either by standard polyacrylamide DNA sequencing gel or by capillary electrophoresis on an ABI PRISM 310 Genetic Analyzer (PE Applied Biosystems, Foster City, California). PCR products from tumor and corresponding control DNA were analyzed in parallel. We followed the recently assessed criteria for the definition of MSI-H (Boland et al, 1998).

Frameshift mutations at coding mononucleotide repeats within TGF $\beta R I I, B A X, h M S H 3, h M S H 6$, IGFIIR, 
and CASP-5 genes were investigated by PCR. Reactions were carried out with either radiolabeled or fluoresceinated specific primers (Malkhosyan et al, 1996; Markowitz et al, 1995; Rampino et al, 1997; Schwartz et al, 1999; Souza et al, 1996). PCR products were analyzed as reported above.

\section{hGARE Gene Mutation Analysis}

A 100-bp fragment of $h G A R E$ exon 5, encompassing the $(T)_{8}$ repeat (GenBank sequence ID L10822), was amplified with the primers 5'-GGCCAAGCTGCTGGCTAAGAA-3' (forward) and 5'-GCCACGTGTTGGCACTATAAAC-3' (backward). PCR was carried out on a $25-\mu$ l volume containing $50-100 \mathrm{ng}$ of template DNA; $0.2 \mu \mathrm{M}$ of each primer; $200 \mu \mathrm{M}$ of dGTP, dCTP, dTTP, and dATP; $1.5 \mathrm{~mm}$ of $\mathrm{MgCl}_{2} ; 1$ unit of Taq "GOLD" polymerase (PE Applied Biosystems); 1x buffer supplied with the enzyme. The reaction was carried out as follows: 1 cycle consisting of 10 minutes at $95^{\circ} \mathrm{C}$ and 35 cycles each consisting of 30 seconds at $94^{\circ} \mathrm{C}, 30$ seconds at $55^{\circ} \mathrm{C}$, and 30 seconds at $72^{\circ} \mathrm{C}$. Alternatively, PCR was carried out in a 50- $\mu$ l volume containing 50-100 ng of template DNA; $0.2 \mu \mathrm{M}$ of each unlabeled primer; $100 \mu \mathrm{M}$ of dGTP, dCTP, and dTTP; $12.5 \mu \mathrm{M}$ of dATP; $5 \mathrm{mCi}\left[\alpha^{-}{ }^{35} \mathrm{~S}\right] \mathrm{dATP} ; 1.5 \mathrm{~mm}$ of $\mathrm{MgCl}_{2}$; 1 unit of Taq "GOLD" polymerase; and $1 \mathrm{x}$ buffer supplied with the enzyme. The reaction was performed as above.

PCR products were analyzed in denaturing conditions, either by capillary electrophoresis (ABI PRISM 310 Genetic Analyzer; PE Applied Biosystems) or by 7-M urea/6\% polyacrylamide sequencing gel electrophoresis. Amplicons with abnormal electrophoretic patterns were subjected to direct sequencing, using cycle-sequencing, either manually (Thermo Sequenase Cycle Sequencing Kit; Amersham Pharmacia Biotech, Uppsala, Sweden) or automatically (ABI PRISM Big Dye Terminator Cycle Sequencing Kit; PE Applied Biosystems, Warrington, United Kingdom).

PCR product from a case of interest was subcloned in a pCR Vector (TA Cloning Kit; InVitrogen Corporation/Novex, Carlsbad, California) following the manufacturer's instructions; cloned fragments were sequenced as above reported.

\section{Detection of hGARE mRNA in Cell Lines}

Total RNA was extracted from LoVo and HCT116 cell lines by using TRIZOL (Life Technologies, Paisley, United Kingdom) according to the manufacturer's instructions. After treatment with DNAase (Amersham Pharmacia Biotech), RNA was reverse-transcribed (RT) using oligo-dT ${ }_{12-18}$ primers and SuperScript II reverse-transcriptase (Life Technologies), according to manufacturer's recommendations. hGARE mRNA level was assessed by 30 -cycle PCR (one cycle $94^{\circ} \mathrm{C}$ for 30 seconds, $58^{\circ} \mathrm{C}$ for 30 seconds, $72^{\circ} \mathrm{C}$ for 40 seconds) with specific primers mapping in exons 4 (forward, 5'-CTCGCGAGCTCTACTTAGGG-3') and 5 (backward, 5'-GTGAATGAAGGAGATAGGAGCAC-3'). To allow $h G A R E$ expression level assessment, $\beta$-actin and hGARE mRNA were coamplified. The $\beta$-actin primers were: 5'-ACCAACTGGGACGACATGGA-3' (forward); and 5'-GCATACCCCTCGTAGATGGG-3' (backward). RT-PCR products were run on $2 \%$ agarose gel and visualized by ethidium bromide staining. The specific $h$ GARE RT-PCR product was characterized by direct cycle sequencing.

\section{References}

Aaltonen LA, Peltomaki P, Leach FS, Sistonen P, Pylkkanen L, Mecklin JP, Javinen H, Powell SM, Jen J, Hamilton SR, Petersen GM, Kinzler KW, Vogelstein B, and de la Chapelle A (1993). Clues to the pathogenesis of familial colorectal cancer. Science 260:812-816.

Bader S, Walker M, Hendrich B, Bird A, Bird C, Hooper M, and Wyllie A (1999). Somatic frameshift mutations in the MBD4 gene of sporadic colon cancers with mismatch repair deficiency. Oncogene 18:8044-8047.

Boland CR, Thibodeau SN, Hamilyon SR, Sidransky D, Eshleman JR, Burt RW, Meltzer J, Rodriguez-Bigas A, Fodde R, Ranzani GN, and Srivastava S (1998). A National Cancer Institute workshop on microsatellite instability for cancer detection and familial predisposition: Development of international criteria for the determination of microsatellite instability in colorectal cancer. Cancer Res 58:5248-5257.

Charbonnier F, Raux G, Wang Q, Drouot N, Cordier F, Limacher JM, Saurin JC, Puisieux A, Olschwang S, and Frebourg T (2000). Detection of exon deletions and duplications of the mismatch repair genes in hereditary nonpolyposis colorectal cancer families using multiplex polymerase chain reaction of short fluorescent fragments. Cancer Res 60:2760-2763.

Curia MC, Palmirotta R, Aceto G, Messerini L, Veri MC, Crognale S, Valanzano R, Ficari F, Fracasso P, Stigliano V, Tonelli F, Casale V, Guadagni F, Battista P, MarianiCostantini R, and Cama A (1999). Unbalanced germ-line expression of hMLH1 and hMSH2 alleles in hereditary nonpolyposis colorectal cancer. Cancer Res 59:3570-3575.

Dietmaier W, Wallinger S, Bocker T, Kullmann F, Fishel R, and Ruschoff J (1997). Diagnostic microsatellite instability: Definition and correlation with mismatch repair protein expression. Cancer Res 57:4749-4756.

Duval A, Gayet J, Zhou XP, lacopetta B, Thomas G, and Hamelin R (1999a). Frequent frameshift mutations of the TCF-4 gene in colorectal cancers with microsatellite instability. Cancer Res 59:4213-4215.

Duval A, lacopetta B, Ranzani GN, Lothe RA, Thomas G, and Hamelin R (1999b). Variable mutations frequencies in coding repeats of TCF-4 and other target genes in colon, gastric and endometrial carcinoma showing microsatellite instability. Oncogene 18:6806-6809.

Duval A, Rolland S, Compoint A, Tubacher E, lacopetta B, Thomas G, and Hamelin R (2001). Evolution of instability at coding and non-coding repeat sequences in human MSI-H colorectal cancers. Hum Mol Genet 10:513-518.

Herman JG, Umar A, Polyak K, Graff J, Ahuja N, Issa J, Markowitz S, Willson J, Hamilton S, Kinzler K, Kane M, Kolodner R, Vogelstein B, Kunkel T, and Baylin S (1998). Incidence and functional consequences of hMLH1 promoter hypermethylation in colorectal carcinoma. Proc Natl Acad Sci USA 95:6870-6875. 
Ionov Y, Peinado MA, Malkhosyan S, Shibata D, and Perucho M (1993). Ubiquitous somatic mutations in simple repeated sequences reveal a new mechanism for colonic carcinogenesis. Nature 363:558-561.

Iwase K, Evers BM, Hellmich MR, Guo YS, Higashide S, Kim $\mathrm{HJ}$, and Townsend M Jr (1997). Regulation of growth of human gastric cancer by gastrin and glycine-extended progastrin. Gastroenterology 113:782-790.

Kane MF, Loda M, Gaida GM, Lipman J, Mishra R, Goldman H, Jessup JM, and Kolodner R (1997). Methylation of the hMLH1 promoter correlates with lack of expression of hMLH1 in sporadic colon tumors and mismatch repairdefective human tumor cell lines. Cancer Res 57:808-811.

Kusyk CJ, McNiel NO, and Johnson LR (1986). Stimulation of growth of a colon cancer cell line by gastrin. Am J Physiol 251:G597-G601.

Liu B, Nicolaides NC, Markowitz S, Willson JK, Parsons RE, Jen J, Papadoulos N, Peltomaki P, de la Chapelle A, Hamilton SR, Kinzler KW, and Vogelstein B (1995). Mismatch repair gene defects in sporadic colorectal cancers with microsatellite instability. Nat Genet 9:48-55.

Malkhosyan S, Rampino N, Yamamoto H, and Perucho M (1996). Frameshift mutator mutations. Nature 382:499-500.

Markowitz SD, Wang J, Myeroff L, Parsons R, Sun L, Lutterbaugh J, Fan RS, Zborowska E, Kinzler KW, Vogelstein B, Brattain M, and Wilson JKV (1995). Inactivation of the type II TGF- $\beta$ receptor in colon cancer cells with microsatellite instability. Science 268:1336-1338.

Matus-Leibovitch N, Nussenzveig DR, Gershengorn MC, and Oron $Y$ (1995). Truncation of the thyreotropin-releasing hormone receptor carboxyl tail causes constitutive activity and leads to impaired responsiveness in Xenopus oocytes and AtT20 cells. J Biol Chem 270:1041-1047.

McWilliams DF, Watson SA, Crosbee DM, Michaeli D, and Seth $R$ (1998). Coexpression of gastrin and gastrin receptors (CCK-B and delta CCK-B) in gastrointestinal tumour cell lines. Gut 42:795-798.

Monstein HJ, Nylander AG, Salehi A, Chen D, Lundquist I, and Hakanson R (1996). Cholecystokinin-A and cholecystokinin-B/gastrin receptor mRNA expression in the gastrointestinal tract and pancreas of the rat and man. A polymerase chain reaction. Scand J Gastroenterol 31:383-390.

Peltomaki $P$ (2001). Deficient DNA mismatch repair: A common etiologic factor for colon cancer. Hum Mol Genet 10:735-740.

Peltomaki P and Vasen HF (1997). Mutations predisposing to hereditary nonpolyposis colorectal cancer: Database and results of a collaborative study. The International Collaborative Group on Hereditary Nonpolyposis Colorectal Cancer. Gastroenterology 113:1146-1158.

Piao Z, Fang W, Malkhosyan S, Kim H, Horii A, Perucho M, and Huang $S$ (2000). Frequent frameshift mutations of RIZ in sporadic gastrointestinal and endometrial carcinomas with microsatellite instability. Cancer Res 60:4701-4704.

Pohl M, Silvente-Poirot S, Pisegna JR, Tarasova NI, and Wank SA (1997). Ligand-induced internalization of cholecystokinin receptors. J Biol Chem 272:18179-18184.

Rampino N, Yamamoto H, lonov Y, Li Y, Sawai H, Reed JC, and Perucho M (1997). Somatic frameshift mutations in the $B A X$ gene in colon cancers of the microsatellite mutator phenotype. Science 275:967-969.
Riccio A, Aaltonen LA, Godwin AK, Loukola A, Percesepe A, Salovaaara R, Masciullo V, Genuardi M, Paravatou-Petsotas M, Bassi DE, Ruggeri BA, Klein-Szanto AJP, Testa JR, Neri $\mathrm{G}$, and Bellacosa A (1999). The DNA repair gene MBD4 (MED1) is mutated in human carcinomas with microsatellite instability. Nat Genet 23:266-268.

Schwartz S Jr, Yamamoto H, Navarro M, Maestro M, Reventòs J, and Perucho M (1999). Frameshift mutations at mononucleotide repeats in caspase- 5 and other target genes in endometrial and gastrointestinal cancer of the microsatellite mutator phenotype. Cancer Res 59:2995-3002.

Seva C, Dickinson CJ, and Yamada T (1994). Growth promoting effects of glycine-extended progastrin. Science 265: 8429-8438.

Singh P, Xu Z, Dai B, Rajaraman S, Rubin N, and Bhrwa B (1994). Incomplete processing of progastrin expressed by human colon cancer cells: Roles of noncarboxyamidated gastrins. Am J Physiol 166:G459-G468.

Song I, Brown DR, Wiltshire RN, Gantz I, Trent JM, and Yamada T (1993). The human gastrin/cholecystokinin type B receptor gene: Alternative splice donor site in exon 4 generates two variant mRNAs. Proc Natl Acad Sci USA 90:9085-9089.

Souza RF, Appel R, Yin J, Wang S, Smolinski KN, Abraham JM, Zou TT, Shi YO, Lei J, Cottrell J, Cyme K, Biden K, Simms L, Leggett B, Lynch PM, Frazier M, Powell SM, Harpaz N, Sugimura H, Young J, and Meltzer SJ (1996). Microsatellite instability in the insulin-like growth factor II receptor gene in gastrointestinal tumors. Nat Genet 14:255-257.

Stepan VM, Sawada M, Todisco A, and Dickinson CJ (1999). Glycine-extended gastrin exerts growth-promoting effects on human colon cancer cells. Mol Med 5:147-159.

Thibodeau SN, Bren G, and Schaid D (1993). Microsatellite instability in cancer of the proximal colon. Science 260:812-819.

Thomas WG, Thekkumkara TJ, Motel TJ, and Baker KM (1995). Stable expression of a truncated AT1A receptor in $\mathrm{CHO}-\mathrm{K} 1$ cells. The carboxyl-terminal region directs agonistinduced internalization but not receptor signaling or desensitization. J Biol Chem 270:207-213.

Vilkki S, Tsao JL, Loukola A, Poyhonen M, Vierimaa O, Herva $R$, Aaltonen LA, and Shibata D (2001). Extensive somatic microsatellite mutations in normal human tissue. Cancer Res 61:4541-4544.

Wank SA (1998). G-protein-coupled receptors in gastrointestinal physiology. CCK receptors: An exemplary family. Am J Physiol 274:G607-G613.

Watson SA, Clarke PA, Smith AM, Varro A, Michaeli D, Grimes S, Caplin M, and Hardcastle JD (1998). Expression of $\mathrm{CCKB} /$ gastrin receptor isoforms in gastro-intestinal tumour cells. Int J Cancer 77:572-577.

Yamamoto H, Sawai H, and Perucho M (1997). Frameshift mutations in gastrointestinal cancer of the microsatellite mutator phenotype. Cancer Res 57:4420-4426.

Zhang L, Yu J, Willson JK, Markowitz SD, Kinzler KW, and Vogelstein B (2001). Short mononucleotide repeat sequence variability in mismatch repair-deficient cancers. Cancer Res 61:3801-3805. 